\title{
Using business process improvement concept to optimize enterprise production system in conditions of innovative economic development
}

\author{
Elena S. Palkina ${ }^{1, *}$ \\ ${ }^{1}$ Transportation Economics Department, Emperor Alexander I St. Petersburg State Transport \\ University, 9 Moskovsky pr., 190031, Saint Petersburg, Russia
}

\begin{abstract}
Innovation is the basis of economic growth. Currently, they are mainly subordinated to the goal of creating a digital economy. The article is devoted to creation of research methodology in the field of production and economic system development processes, real and potential results of its functioning on the basis of the business processes improvement concept that will serve the making managerial decisions, implementation of the innovative scenario of the Russian enterprises strategic development, increase of their competitiveness in the world market.
\end{abstract}

\section{Introduction}

The new postindustrial technological mode is based on knowledge economy - the economy of society, based on knowledge, innovation, on the friendly perception of new ideas, on the readiness of their practical implementation in various spheres of human activity. Biotechnologies, systems and technologies of artificial intelligence for various functional purposes, global and local information networks and telecommunication systems, nanotechnology, environmental management, energy conservation, high-speed transport systems are becoming key areas of the new technological order. By the way, flexible automation of production on the basis of intelligent systems, the production of structural materials with predetermined properties, non-traditional energy sources will get further development.

An important step towards the creation of innovative economy in addition to the development of science is innovative activity of Russian enterprises. Effective realization of the production potential of domestic enterprises on innovative basis is one of the main conditions for accelerated economic growth, increasing investment attractiveness and competitiveness.

In the context of development of the Russian economy on the basis of knowledge according to the Strategy of development of the information society in the Russian Federation for 2017 - 2030 [1], an important role is given to the innovative renewal of the industry.

\footnotetext{
*Corresponding author: elena palkina@hotmail.com
} 


\section{Setting the task}

The development of the organization should be defined as a transition from one state to another, which is considered more effective for its activities. Effective implementation of such a transition requires a number of changes to organizational processes, which entails problems related to the compatibility of old and new procedures and structures. The main changes in the enterprise management model are due to the ongoing processes of digitalization, namely: the use of highly intelligent cognitive technologies, the Internet of Things (IoT), the Industrial Internet of Things (IIoT), big data, augmented reality, the development of cloud technologies $[2,3]$. The new approach requires flexibility and a high speed of response to changes, this is possible if an enterprise switch to a digital business model.

At the same time, according to experts, there are the significant lack of business processes integration on the functional basis, the lack of flexibility in enterprise management, significant level of production errors, insufficiently accurate planning, which lead to decrease in the effectiveness and efficiency of activities, low degree of economic potential realization, increase in unrealized profit [4], noncompliance with stakeholders' expectations. That is why the optimization of production processes is a priority task of modern enterprises seeking to create competitive advantages that are the key to successful operation in a competitive market, namely: to ensure the manufacture of quality products, the use of high technologies, "know-how", the sale of goods at the optimal price, reducing the time spent on the manufacture and supply of products to customers. At the same time, reducing the time for operations, order fulfillment in a situation of rapid changes and unpredictability of environmental conditions is considered by us as the most effective opportunity to obtain a competitive advantage, since reducing the time for business processes leads to saving labor, material and financial resources. Orientation of an enterprise on innovative type of the activity by all means will entail transformation of business model, all components of economic system. Particularly the production system of the enterprise will change dramatically.

In connection with the above, the scientific research, the results of which are presented in this article, is devoted to solving the problem of developing the methodology for studying the processes of production and economic system development, existing (real) and potential results of its functioning, which will serve as the basis for management decisions and implementation of an innovative scenario of the organization development strategy in order to improve its competitiveness in the world market.

\section{Conceptual framework}

To solve this problem, the concept of business processes improvement (BPI) was used, which determines the methodology of strategic planning aimed at identifying operations, formation of skills of employees that can be improved to raise performance, ensure economic growth of business, and based on the principles of universality, process orientation, continuity of the improvement process [5-7]. It should be noted that the main provisions are based on the widely presented in the scientific literature PDCA improvement cycle: «Plan - Do - Check - Act», methodology, which was developed by E. Deming [8].

According to the theory of growth based on innovation, the issue of stimulating economic growth is directly related to the increase in the intensity of innovation activities at the enterprise level, which in turn is determined by the expected profit from investments in research and development [9].

In addition, in the course of the study the author relied on the provisions of the own concept of system-integrated management, which is described in the works [10-12]. 


\section{Results}

We highlighted the main characteristics of the innovation economy. Firstly, information (artificial intelligence) and knowledge (human intellectual capital) are becoming the main economic resources. Secondly, informatization of all life activity spheres is expanding. Thirdly, there is a process of reducing the life cycle of goods and services, diffusion and acceleration of interdisciplinary, intersectoral knowledge flows. In addition, there is a rethinking of the man role of in the economy, the level of his intellectual and spiritual development. Employees labor becomes more creative, knowledge-intensive. The employee's innovation, research and creative potentials are embodied in material and nonmaterial production processes. Intellectual capital creates the basis for the formation of innovative and, as a consequence, financial capital. Intellectualization of economic relations requires fundamental changes in the system of enterprise management.

To be successful in modern conditions of the Russian economy, the enterprise needs to pay special attention to innovative activity. The receivers of innovations can be means of production, technological processes, manufactured products, human capital, organizational development, etc. All these components are directly related to the quality characteristics of the production process, determine its efficiency, productivity, safety, environmental friendliness, etc. Based on these changes, the enterprise production system, engaged in innovative activity, was characterized.

The comparative analysis of the traditional (not carrying out innovative activity) and innovative enterprise is presented in table 1 .

Table 1. Distinctive features of innovative enterprise

\begin{tabular}{|c|c|c|}
\hline Comparison criteria & Traditional enterprise & Innovative enterprise \\
\hline $\begin{array}{l}\text { Organizational } \\
\text { structure }\end{array}$ & linear, linear-functional & matrix, project, network \\
\hline $\begin{array}{l}\text { Status of an } \\
\text { employee }\end{array}$ & $\begin{array}{l}\text { defined and fixed position } \\
\text { of the employee }\end{array}$ & $\begin{array}{l}\text { corresponds to knowledge, abilities, skills, } \\
\text { the saved-up professional competences }\end{array}$ \\
\hline Management style & directive & democratic \\
\hline $\begin{array}{l}\text { The principle of } \\
\text { decision-making }\end{array}$ & $\begin{array}{l}\text { management based on } \\
\text { instructions }\end{array}$ & $\begin{array}{l}\text { solutions depend on each specific situation, } \\
\text { flexibility in data and tasks modification } \\
\text { processes }\end{array}$ \\
\hline $\begin{array}{l}\text { The credentials of } \\
\text { the employee }\end{array}$ & $\begin{array}{l}\text { limited by rules and } \\
\text { conventions }\end{array}$ & $\begin{array}{l}\text { the possibility of initiative and independent } \\
\text { solutions to the questions }\end{array}$ \\
\hline Attitude to conflicts & negative & debate, disputes are permitted \\
\hline $\begin{array}{l}\text { Interaction of } \\
\text { employees with } \\
\text { each other }\end{array}$ & missing or minimized & $\begin{array}{l}\text { emphasis on constant interaction, exchange } \\
\text { of information and opinions }\end{array}$ \\
\hline $\begin{array}{l}\text { Relation to } \\
\text { information }\end{array}$ & $\begin{array}{l}\text { information closeness, } \\
\text { inaccessibility }\end{array}$ & $\begin{array}{l}\text { information is available, communications are } \\
\text { welcome, «open innovation» model }\end{array}$ \\
\hline $\begin{array}{l}\text { Integration with } \\
\text { science }\end{array}$ & absents & $\begin{array}{l}\text { use of advanced achievements of science and } \\
\text { technology, cooperation with knowledge } \\
\text { production centers }\end{array}$ \\
\hline
\end{tabular}


The work can be organized in such a way that the enterprise will be a self-regulating system that is capable of identifying and correcting deficiencies independently and in a timely manner. The relevant process is a cycle of systematic and orderly work on continuous improvement of the organization's activities and personal improvement.

Having considered and systematized the main provisions of the above concepts, the author developed an approach to the continuous business processes improvement to optimize the enterprise production system in conditions of innovative economic development in the form of a model of continuous improvement based on the process approach (Fig. 1). The reason for fundamental changes may be innovations in the materials used, production technologies, information support. Thus, on the example of the machinebuilding enterprise for the production of locomotives, changes in the production processes of the enterprise can be due to the use of automated vehicle control technologies, the use of composite materials, implementation of the IIoT, electronic marketing in the enterprise management system.

The main modules of the modified production system, adapted to the conditions of the digital economy, are: 1) production systems and their components, 2) labor organization, 3) quality management tools, 4) analysis and evaluation of production tasks performance, 5) process approach in the organization of production, 6) production logistics, 7) high technologies (cloud, cognitive, etc.), 8) cooperative relationships with scientific and educational organizations, 9) process assessment indicators, 10) risks.

\section{Conclusion}

The proposed approach to ensuring transition from the initial state of the enterprise production system to the scenario of improved processes is applicable to change management in the field of enterprises business processes of any industry in conditions of innovative development of economy. It allows to implement proactively new technologies, produce innovative products, focusing on customer needs, constantly improve the quality of goods while ensuring resource savings, reducing time spent on production, improve the professional level of development, motivation, implementation of the creative potential of the staff through the effect of their involvement in key decisions, to debug the interaction with customers, contractors, research centers, thereby increasing competitiveness, sales and business value of enterprises. This will increase innovation and investment activity of domestic organizations and will create the strategic prerequisites for long-term sustainable development of Russia on this basis.

Author is grateful for financial support Russian Foundation for Basic Research. The scientific research was supported by the Russian Foundation for Basic Research within the framework of the project № 18-410-920016 p_a "Research of socio-economic and ecological processes of Sevastopol with the growth of industrial, traffic, transit and tourist potentials". 


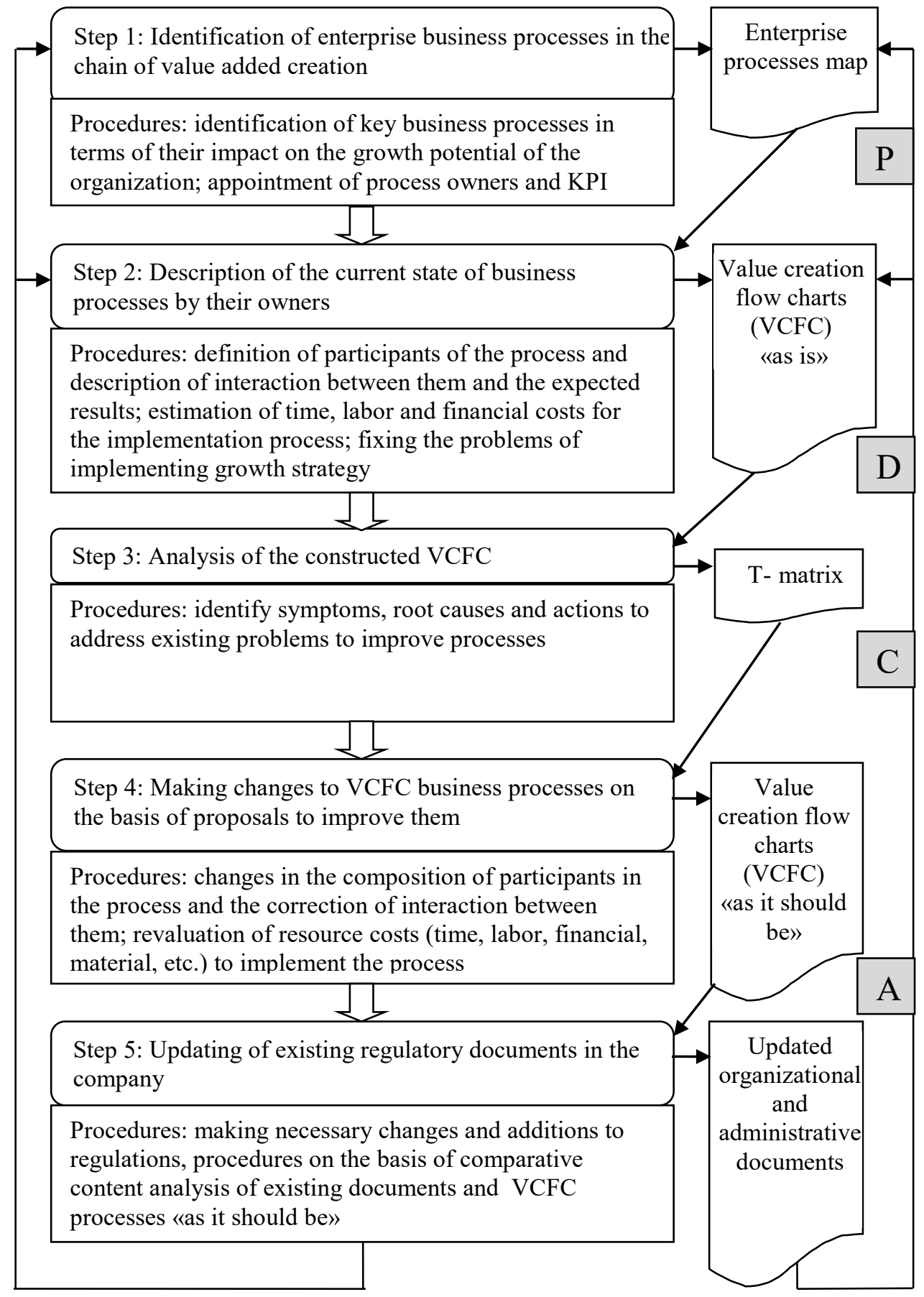

Fig. 1. Algorithmic model of business processes improvement for optimizing enterprise production system 


\section{References}

1. The decree of the President of the Russian Federation from 09.05.2017 № 203 «About the Strategy of information society development in the Russian Federation for 20172030 years» $(2017)$

2. Program «Digital economy of the Russian Federation»: approved by the order of the Government of the Russian Federation on July 28, 2017 №1632-r (2017)

3. A. V. Keshelava, V. G. Budanov, Introduction to digital economics, VNIIGeosystem, M., 28 p. (2017)

4. E. S. Palkina, Financial sources of the Russian railway companies growth, Railways Economics, 10, pp. 48-54 (2016)

5. W. Detmer, Goldratt's theory of limitations: systematic approach to continuous improvement, Al'pina Pablisher, M., 443 p. (2012)

6. I. Masaaki, Kaizen. The key to Japanese companies success, Al'pina Business Books, M., 270 p. (2004)

7. G. Stuart, Training of organizational changes, Peter, SPb., 256 p. (2001)

8. G. Niv, Organization as a system: principles of building a sustainable business of Edwards Deming, Al'pina Pablisher, M., 368 p. (2018)

9. J.A. Schumpeter, Theory of economic development, Direct Media Publishing, M., 400 p. (2008)

10. E. S. Palkina, Growth strategy management system-integrated concept for transport company, Bulletin of the Leningrad State University named after A. S. Pushkin, 3, pp. 69-77 (2013)

11. E. S. Palkina, Economic mechanism of railway company competitiveness increase, Railways Economics, 3, pp. 68-74 (2013)

12. E.S. Palkina, Innovative Imperatives for Competitiveness of National Transport Systems in Conditions of Globalization, Globalization and Its Socio-Economic Consequences, II, pp. 839-846 (2016) 